https://doi.org/10.31470/2706-7904-2020-15-84-88

\title{
UNDERSTANDING LANGUAGE AND SPEECH IN THE VOICE OF COLLECTIVE TRAUMA
}

Розуміння мови і мовлення як голосу колективної травми

\author{
Larysa Zasiekina \\ Ph.D. in Clinical Psychology and Psycholinguistics, Professor, \\ Vice-Rector of Research and International Affairs \\ Lesya Ukrainka Volyn National University (Ukraine) \\ zasyekina.larisa@vnu.edu.ua \\ https://orcid.org/0000-0001-8456-0774 \\ Tetyana Hordovskya \\ Postgraduate Student in Psychology \\ Lesya Ukrainka Volyn National University (Ukraine) \\ Tetiana@vnu.edu.ua \\ https://orcid.org/0000-0002-0445-9615

\section{Mariia Kozihora} \\ Postgraduate Student in Psychology \\ Lesya Ukrainka Volyn National University (Ukraine) \\ kozihoramariia@gmail.com \\ https://orcid.org/0000-0001-9597-952X
}

\begin{abstract}
The study aims to examine lexicon of collective trauma and compare it with concepts of posttraumatic stress disorder (PTSD), moral injury and continuous traumatic stress (CTS). The role of language and speech in disintegrating and constructing meaning as a result of collective trauma has been explored.
\end{abstract}

Key words: collective trauma, moral injury, continuous traumatic stress, psycholinguistic meaningful categories.

\section{Introduction}

There is a growing body of literature that recognises the importance of collective trauma in terms of transgenerational nature, mental health, identity and construction of 
meaning. Central to the entire discipline of psycholinguistics is the concept of meaning which leads to understanding the voice of all participants in collective trauma, particularly perpetrators, bystanders and rescues. Vygotsky (2014) points out that meaning is the act of cognitive generalization and communication, therefore, the meaning of collective trauma is an act of understanding the horrified traumatic event through narrating it in collective life story. It is now well established that collective trauma can impair the meaning of self for national or ethnic group and is one of the main obstacles in developing national and ethnic identity (Kira et al., 2008). Moreover, collective trauma is associated with historic trauma, trauma of identity and genocide, moral injury and conditions of CTS (Coady, Carney, Frankfurt \& Litz, 2020). Findings from recent research indicate transgenerational mechanisms of collective trauma, manifesting in PTSD symptoms in direct descendants of collective trauma (Bezo \& Maggi, 2015).

Despite the importance of collective trauma in terms of individual and social safety, there remains a paucity of evidence on how language and speech in collective trauma contribute to constructing meaning. One of the main obstacles is expanded lexicon for collective trauma, in particular post-traumatic stress disorder (PTSD), moral injury, and CTS continuous traumatic stress (CTS). The purpose of this paper is to review recent research of collective trauma and explore expanded scope of its lexicon, in particular PTSD, CTS and moral injury in terms of constructing meaning aligned with traumatic event.

\section{Research Methods and Techniques}

One of the most well-known tools for exploring the boarders of the concept is conceptual analysis. Conceptual analysis was prepared according to the procedure used by Zasiekina (2005). The procedure includes searching for the main notions in lexicon of collective trauma, PTSD, CTS and moral injury considering category of meaning as an act of interpreting and understanding traumatic event. The study applies a descriptive approach to examine collective trauma, PTSD, CTS and moral injury from the perspective of constructing meaning. The structural literature review encompasses articles in peerreviewed journals from 2008 to 2020. The databases Psyc-Info and PubMed were searched using an inclusion criterion for the articles, notably articles, exploring collective trauma, PTSD, CTS and moral injury from the perspective of constructing meaning. The initial corpus contained 57 articles, after the selection procedure considering an inclusion criterion 18 articles were chosen. The results are summarized in Table 1.

PTSD is an anxiety disorder arising as a delayed and protracted response after experiencing or witnessing a traumatic event involving actual or threatened death or serious injury to self or others (Guha, 2006). Evidence consistently suggests that making a certain 
meaning of traumatic event in PTSD, indexed in post-traumatic conditions, has a strong effect on developing or preventing PTSD after experiencing trauma. Therefore, the main factor of PTSD is rather more aligned with constructing meaning of traumatic event than with event itself (Cromer \& Smyth, 2010).

Moral injury, on the contrary of PTSD, is not defined as an anxiety disorder and relates to disintegrating meaning considering morality, notably moral standards, moral reasoning, moral behaviour, and moral emotions (Zasiekina \& Zasiekin, 2020). Barnes, Hurley, \& Taber (2019) argue that witnessing morally traumatic situation does not always lead to PTSD. The main predictor of developing PTSD in potentially morally injurious events is constructing meaning of the event, which expresses the dissonance between moral standards and real behavior resulting in moral emotions of shame and guilt (Griffin et al., 2019). In addition, McDonald (2017) expands moral emotions to disgast, anger, and embarrassment.

CTS similar to moral injury is not defined as an anxiety disorder, it is a living condition, which is characterized by permanent threat. Eagle and Kaminer (2013) define CTS considering the context of the stressor conditions, the temporal location of the stressor conditions, the complexity of discriminating between real and perceived threat, and the absence of external protective systems. Nuttman-Shwartz and Shoval-Zuckerman (2016) defines CTS as patterns of emotions, behaviors, and perceptions among individuals, families, communities, and societies. The most important idea for our study is that developing the most efficient coping strategy for CTS depends on past and future constructing meaning of threat, which determines the patterns of emotions and behaviours.

\section{Results}

In summary, the results of structural literature review and conceptual analysis of collective trauma, PTSD, CTS and moral injury considering category of meaning are shown in Table 1.

Table1. Results of structural literature review and conceptual analysis of lexicon of collective trauma, PTSD, CTS and moral injury

\begin{tabular}{|l|l|l|l|}
\hline & Concepts and authors & \multicolumn{1}{|c|}{ Main notions } & Reference for meaning \\
\hline 1. & $\begin{array}{l}\text { PTSD (Cromer \& Smyth, } \\
\text { 2010) }\end{array}$ & $\begin{array}{l}\text { Anxiety disorder, response, } \\
\text { traumatic event }\end{array}$ & $\begin{array}{l}\text { Constructing meaning } \\
\text { of traumatic event and } \\
\text { self in traumatic } \\
\text { situation }\end{array}$ \\
\hline 2. & $\begin{array}{l}\text { Collective trauma (Baum, } \\
\text { 2008; Bezo \& Maggi, 2015; } \\
\text { Coady, Carney, Frankfurt, \& } \\
\text { Litz, 2020; Kira et al., 2008) }\end{array}$ & $\begin{array}{l}\text { Traumatic events, group identity, } \\
\text { historic trauma, trauma of identity, } \\
\text { genocide, transgenerational PTSD, } \\
\text { moral injury, experiencing CTS. }\end{array}$ & $\begin{array}{l}\text { Disintegrating and } \\
\text { constructing meaning of } \\
\text { group self }\end{array}$ \\
\hline
\end{tabular}


3. Moral Injury (Antal \& Disintegrating meaning morality, Dissonance between Winings, 2015; Barnes, moral standards, moral reasoning, meanings of moral Hurley, \& Taber Coady, moral behaviour, and moral beliefs and behaviour Carney, Frankfurt, \& Litz, emotions.

2020; Drescher et al., 2011; Farnsworth et al., 2014; Griffin, 2019; Litz et al., 2019; McDonald, 2017; Zasiekina \& Zasiekin, 2020).

4. CTS (Eagle \& Kaminer, Permenant strees in terms of Past and future meaning 2013; Nuttman-Shwartz \& stressor conditions, the complexity of threat which Shoval-Zuckerman, 2016) of discriminating between real and perceived or threat, and the absence of external protective behaviours. systems.

\section{Conclusions}

This study has raised important questions about the nature of collective trauma, and disintegrating and constructing meaning aligned with its experience. The result has a strong practical application in developing treatment plan for collective trauma, PTSD, CTS and moral injury, which is based on constructing a new meaning in the case of disintegrating meaning towards self, others and the world. Since constructing meaning is closely connected with language and individual speech as a result of cognitive generalization and communication, these findings provide insights for future psycholinguistic research and practice in clinical settings.

\section{References}

Antal, C.J., \& Winings, K. (2015). Moral injury, soul repair, and creating a place for grace. Religious Education, 110(4), 382-394. https://doi.org/10.1080/00344087.2015.1063962

Barnes, H.A., Hurley, R.A., \& Taber, K.H. (2019). Moral injury and PTSD: often co-occurring yet mechanistically different. The Journal of neuropsychiatry and clinical neurosciences, 31(2), A4-103. https://doi.org/10.1176/appi.neuropsych.19020036

Baum, S.K. (2008). The psychology of genocide: Perpetrators, bystanders, and rescuers. Cambridge University Press.

Bezo, B., \& Maggi, S. (2015). Living in "survival mode:" Intergenerational transmission of trauma from the Holodomor genocide of 1932-1933 in Ukraine. Social Science \& Medicine, 134, 87-94. https://doi.org/10.1016/j.socscimed.2015.04.009

Coady, A., Carney, J.R., Frankfurt, S., \& Litz, B.T. (2020). The Emergence and Development of the Concept of Moral Injury. Moral Injury: A Guidebook for Understanding and Engagement, 21. 
Cromer, L.D., \& Smyth, J.M. (2010). Making meaning of trauma: Trauma exposure doesn't tell the whole story. Journal of Contemporary Psychotherapy, 40(2), 65-72. https://doi.org/10.1007/s10879-009-9130-8

Drescher, K.D., Foy, D.W., Kelly, C., Leshner, A., Schutz, K., \& Litz, B. (2011). An exploration of the viability and usefulness of the construct of moral injury in war veterans. Traumatology, 17(1), 8-13. https://doi.org/10.1177/1534765610395615

Eagle, G., \& Kaminer, D. (2013). Continuous traumatic stress: Expanding the lexicon of traumatic stress. Peace and Conflict: Journal of Peace Psychology, 19(2), 85. https://doi.org/10.1037/a0032485

Farnsworth, J.K., Drescher, K.D., Nieuwsma, J.A., Walser, R.B., \& Currier, J.M. (2014). The role of moral emotions in military trauma: Implications for the study and treatment of moral injury. Review of General Psychology, 18(4), 249-262. https://doi.org/10.1037/gpr0000018

Griffin, B.J., Purcell, N., Burkman, K., Litz, B.T., Bryan, C.J., Schmitz, M., ... \& Maguen, S. (2019). Moral injury: an integrative review. Journal of Traumatic Stress, 32(3), 350-362. https://doi.org/10.1002/jts.22362

Griffin, B.J., Purcell, N., Burkman, K., Litz, B.T., Bryan, C.J., Schmitz, M., ... \& Maguen, S. (2019). Moral injury: an integrative review. Journal of Traumatic Stress, 32(3), 350-362. https://doi.org/10.1002/jts.22362

Guha, M. (2006). Oxford Dictionary of Psychology. Reference Reviews.

Kira, I.A., Lewandowski, L., Templin, T., Ramaswamy, V., Ozkan, B., \& Mohanesh, J. (2008). Measuring cumulative trauma dose, types and profiles using a development-based taxonomy of trauma, Traumatology, 14, 62-87. https://doi.org/10.1177/1534765608319324

Litz, B. T., Stein, N., Delaney, E., Lebowitz, L., Nash, W. P., Silva, C., \& Maguen, S. (2009). Moral injury and moral repair in war veterans: A preliminary model and intervention $\begin{array}{llll}\text { strategy. } \quad \text { Clinical } & \text { review, }\end{array}$ https://doi.org/10.1016/j.cpr.2009.07.003

McDonald, J. (Ed.). (2017). Exploring moral injury in sacred texts. Jessica Kingsley Publishers.

Nuttman-Shwartz, O., \& Shoval-Zuckerman, Y. (2016). Continuous traumatic situations in the face of ongoing political violence: The relationship between CTS and PTSD. Trauma, Violence, \& Abuse, 17(5), 562-570. https://doi.org/10.1177/1524838015585316

Shay, J. (2014). Moral injury. Psychoanalytic Psychology, $31(2), 182$. https://doi.org/10.1037/a0036090

Vygotsky (2014) Myshlenie i rech. [Thinking and Speech]. Directmedia.

Zasiekina, L, (2005). Strukturna i funktsionalna organizatsia intelektu [Structural and Functional Organization of Individual Intelligence]. Ostroh, Ostroh Academy Press.

Zasiekina, L., \& Zasiekin, S. (2020). Verbal Emotional Disclosure of Moral Injury in Holodomor Survivors. PSYCHOLINGUISTICS, 28(1), 41-58. https://doi.org/10.31470/2309-1797-202028-1-41-58 